\title{
Oxidative stress biomarkers and paraoxonase 1 polymorphism frequency in farmers occupationally exposed to pesticides
}

\author{
CHIARA COSTA $^{1 *}$, SILVIA GANGEMI ${ }^{1}$, FEDERICA GIAMBÒ ${ }^{1}$, VENERANDO RAPISARDA ${ }^{2}$, \\ DANIELA CACCAMO $^{3}$ and CONCETTINA FENGA ${ }^{1 *}$
}

\author{
${ }^{1}$ Department of The Environment, Security, Territory, Food and Health Sciences, Occupational Medicine Section, \\ G. Martino Hospital, University of Messina, Messina I-98125; ${ }^{2}$ Department of Occupational Medicine, \\ Vittorio Emanuele Hospital, University of Catania, Catania I-95100; \\ ${ }^{3}$ Department of Biomedical Sciences and Morpho-Functional Imaging, \\ University of Messina, Messina I-98125, Italy
}

Received October 28, 2014; Accepted July 10, 2015

DOI: $10.3892 / \mathrm{mmr} .2015 .4196$

\begin{abstract}
Previous evidence has demonstrated that chemical classes of pesticides, including organophosphates (OP), can induce oxidative stress in exposed workers. The resulting increase in free radicals causes damage to biological macromolecules, and promotes the formation of novel compounds, including advanced glycation end products (AGE) and advanced oxidation protein products (AOPP). The present study aimed to evaluate the common genetic polymorphisms of the paraoxonase 1 (PON1) gene in a group of 55 farmers exposed to pesticides, as well as the association between these polymorphisms and serum levels of AGE and AOPP. The 192Q wild-type (WT) allele was present at a significantly higher frequency, compared with the $192 \mathrm{R}$ mutated allele (0.74 and 0.26 , respectively). The WT allele was predominantly represented by the homozygote 192QQ genotype (51\%). The mutated 192QR heterozygotic allele was prevalent, at a frequency of $45.4 \%$, whereas the mutated homozygotes were present at a frequency of $3.6 \%$. A significant decrease in the levels of AGE and AOPP was observed in farmers exhibiting the homozygotic 192RR mutated genotype (14,7221 AU/ml and $0.64 \mathrm{nmol} / \mathrm{ml}$, respectively), compared with the WT genotype $(16,1400 \mathrm{AU} / \mathrm{ml}$ and $1.76 \mathrm{nmol} / \mathrm{ml}$, respectively), and 192QR
\end{abstract}

Correspondence to: Professor Concettina Fenga, Department of The Environment, Security, Territory, Food and Health Sciences, Occupational Medicine Section, G. Martino Hospital, University of Messina, 1 Via Consolare Valeria, Messina I-98125, Italy

E-mail: cfenga@unime.it

*Contributed equally

Abbreviations: OP, organophosphoric; PON, paraoxonase; AOPP, adavanced oxidation protein products; AGE, advanced glycation end-products

Key words: paraoxonase, adavanced oxidation protein products, advanced glycation end-products, pesticides, occupational exposure genotype $(15,2312 \mathrm{AU} / \mathrm{ml}$ and $1.60 \mathrm{nmol} / \mathrm{ml}$, respectively). Therefore, due to the high catalytic activity of PON1, the 192RR genotype provides an important genetic predictor of the toxic effects associated with OP pesticide exposure. It determines a minor risk of developing oxidative damage following pesticide exposure, and measuring the levels of AOPP may provide a novel biomarker for oxidative damage in subjects exposed to OP.

\section{Introduction}

Pesticides constitute a heterogeneous category of chemicals specifically designed for preventing, destroying, repelling or mitigating pests (1). However, pesticides represent a problem to public health due to their presence in living and working environments. Thus, almost all individuals are inevitably exposed to low levels of pesticides due to environmental contamination or intentional use (2). In addition, certain populations, including farmers and greenhouse workers, may receive higher exposure to pesticides. Although the acute toxic effects resulting from pesticide exposure are easily recognized in these subjects, the effects resulting from long-term exposure to low doses are often difficult to assess $(3,4)$. Several studies have reported associations between exposure to agricultural chemicals and various deleterious health outcomes, including effects on the immune, hematological, nervous, endocrine and reproductive systems (5-7). These compounds have also been associated with DNA damage in human populations $(8,9)$, various types of cancer (10-14) and degenerative diseases (15). Previous toxicological and epidemiological studies have demonstrated that pyrethroid, organochlorine and organophosporic (OP) pesticides may induce oxidative stress, which is expressed as changes in the antioxidative parameters, including changes in the activity of antioxidant enzymes (16-19). Oxidative stress is an imbalance between the production of reactive oxygen species and antioxidants, in favor of free radicals. Toxic effects are induced by the production of peroxides and free radicals, which damage important biological structural proteins, carbohydrates, lipids and nucleic acids, and may enhance inflammatory responses (18). Novel compounds and modified 
structures, which can serve as markers of these mechanisms, are formed, including advanced oxidation protein products (AOPP), advanced glycation end-products (AGE) and advanced lipoperoxidation end-products (ALE) (20). The majority of these products have been suggested for use as risk evaluation biomarkers for oxidative damage in workers exposed to pesticides (21).

Several studies have demonstrated that human paraoxonase 1 (PON1) is involved in the protection against exposure to common OP insecticides, due to its ability to hydrolize toxic oxon metabolites at physiologically relevant rates (22-25). Serum PON1 belongs to a family of PONs, which has a total of three members located in the 7q21.3-22.1 chromosomal region (26). The activity levels of PON1 vary significantly between individuals, and this variation is currently attributed to the presence of polymorphisms in the PON1 gene, amongst other factors (27). The two most important genetic variations, which have been described are Q192R and L55M, each of which involves a single amino acid substitution. The $\mathrm{R}$ isoform has arginine at position 192, whereas the Q isoform has glutamine at this position. The PON1 192QR polymorphism is involved in enhanced hydrolysis of paraoxon and chlorpyrifos oxon, whereas the PON1 55LM polymorphism is hypothesized to be associated with low serum concentrations of the enzyme (28).

These polymorphisms, together with environmental effects and population characteristics, including gender, age and nutrient intake, are responsible for the observed variation in serum PON1 activity levels between individuals (up to 40 -fold) (23). Therefore, genotypic characterization of the PON1 gene represents a potential predictor for susceptibility to OP pesticides.

The present study aimed to evaluate the frequency of the most common genetic polymorphism of the PON1 gene in a group of farmers exposed to pesticides, and to investigate the association between these polymorphisms and the serum levels of AOPP and AGE.

\section{Materials and methods}

Subject characteristics. A total of 55 males, employed at a farm located in eastern Sicily, Italy, were selected for inclusion in the present study. All participants were Caucasian, aged between 19 and 65 years and had been employed for $23.07 \pm 13.85$ years. The workers were included in a medical surveillance program for the prevention of occupational diseases, and provided written informed consent for this survey. A questionnaire was used to collect information regarding sociodemographic characteristics (age and gender), lifestyle (smoking habits, alcohol and drug consumption and fruit and vegetable intake) and occupational features (lifetime exposure to pesticides, use of personal protective equipment and type of pesticide used), and to confirm the absence of known disorders or diseases in the three months preceding the survey. Patients provided written informed consent.

Genotyping. Briefly, $3 \mathrm{ml}$ peripheral blood samples were collected from each participant in vacuum tubes containing K3-EDTA. Genomic DNA was then isolated from peripheral blood lymphocytes in a blood sample volume of $300 \mu \mathrm{l}$ using the Gentra PureGene DNA Purification system (Qiagen,
Table I. Sociodemographic characteristics and lifestyle of subjects.

\begin{tabular}{|c|c|}
\hline Characteristic & Number $(\%)$ \\
\hline Number of subjects & 55 \\
\hline \multicolumn{2}{|l|}{ Gender } \\
\hline Male & 55 \\
\hline Female & 0 \\
\hline Age (years) & $42.08 \pm 12.78$ \\
\hline Length of employment (years) ${ }^{\mathrm{a}}$ & $23.07 \pm 13.85$ \\
\hline Ethnicity & Caucasian \\
\hline \multicolumn{2}{|l|}{ Smoking status ${ }^{\mathrm{b}}$} \\
\hline Smoker & $18(32.7)$ \\
\hline Non-smoker & $37(67.3)$ \\
\hline \multicolumn{2}{|l|}{ Fruit and vegetables ${ }^{\mathrm{c}}$} \\
\hline Yes & $46(83.6)$ \\
\hline No & $9(16.4)$ \\
\hline \multicolumn{2}{|l|}{ Alcohol consumption $^{\mathrm{d}}$} \\
\hline Yes & $4(7.3)$ \\
\hline No & $51(92.7)$ \\
\hline \multicolumn{2}{|l|}{ Personal protective equipment } \\
\hline Yes & $55(100)$ \\
\hline No & 0 \\
\hline
\end{tabular}


cides; ${ }^{\text {bSmoker, }}>10$ cigarettes/day; ${ }^{c}>3$ servings/day. ${ }^{\mathrm{d}}>2$ glasses of wine or beer or one serving of liquor/day.

Milan, Italy), based on protein precipitation by a salting out technique, according to the manufacturer's instructions. Isolated DNA was resuspended in $100 \mu 1$ hydration solution; then, $5 \mu 1$ DNA was mixed with $5 \mu 1$ Tris-EDTA (pH 8.0) and $2 \mu \mathrm{l}$ of $6 \mathrm{X}$ bromophenol blue. The DNA was then subjected to a qualitative analysis by $0.8 \%$ agarose gel electrophoresis in Tris-EDTA acetate buffer at $100 \mathrm{~V}$ for $1 \mathrm{~h}$ on electrophoresis apparatus (Varigel, SciePlas, Cambridge, UK). The gel was stained with ethidium bromide $(10 \mu \mathrm{g} / 10 \mathrm{ml}$ TEA) and genomic DNA fluorescent bands were visualized by a UV transilluminator (Vilber-Lourmat, Eberhardzell, Germany). DNA quantification was conducted by taking spectrophotometric measurements at $260 \mathrm{~nm}$, using 1:20 DNA diluted samples (in water) in a final volume of $100 \mu 1$. Spectrophotometric readings were taken using a Biophototometer plus (Eppendorf, Hamburg, Germany).

Genotyping of the PON1 Q192R polymorphism was performed using reverse transcription-polymerase chain reaction (PCR) allelic discrimination technique on a 7500 Real-time PCR instrument (Applied Biosystems, Milan, Italy), using a Pre-Designed TaqMan SNP Genotyping Assay (Applied Biosystems; assay ID: C_2548962_20). Briefly, $10 \mathrm{ng}$ genomic DNA was amplified in a PCR reaction containing $10 \mu 1$ of $2 \mathrm{X}$ Genotyping Master mix (Applied Biosystems), $1 \mu \mathrm{l}$ of 20X TaqMan Genotyping assay (including primers and two allele specific TaqMan probes labeled with FAM and VIC fluorophores), and DNAse/RNAase free distilled water 
Table II. Effect of the PON1 genotype on the variability of AGE and AOPP serum levels in farmers exposed to organophosphate pesticides.

\begin{tabular}{lccc}
\hline Genotype & N (frequency $\%)$ & AGE (AU/ml) & AOPP (nmol/ml) \\
\hline Wild type (QQ) & $28(51.0)$ & $16,1400 \pm 39,315$ & $1.76 \pm 1.37$ \\
Heterozygote (QR) & $25(45.4)$ & $15,2312 \pm 29,203$ & $1.60 \pm 0.88$ \\
Mutant homozygote (RR) & $2(3.6)$ & $14,7221 \pm 36,839^{\mathrm{a}}$ & $0.64 \pm 0.14^{\mathrm{b}}$ \\
Q allele & $(0.737)$ & & \\
R allele & $(0.263)$ & & \\
\end{tabular}

Data are presented as the mean \pm standard deviation. ${ }^{\mathrm{a}} \mathrm{P}<0.05$ and ${ }^{\mathrm{b}} \mathrm{P}<0.01$, compared with wild type. AGE, advanced glycation end products; AOPP, advanced oxidation protein products.

to a final volume of $20 \mu \mathrm{l}$. Thermocycling conditions were as follows: Denaturation at $95^{\circ} \mathrm{C}$ for $10 \mathrm{mins}$, then 40 cycles of denaturation at $95^{\circ} \mathrm{C}$ for $15 \mathrm{sec}$, and annealing/extension at $60^{\circ} \mathrm{C}$ for $1 \mathrm{~min}$. Genotype assessment was made on the basis of fluorescent signals (VIC=wild-type allele; and FAM=mutated allele) recorded by a real-time PCR instrument optical system (Applied BioSystems) throughout PCR amplification. Thus, the homozygous wild-type genotype was recognised on the basis of a VIC fluorescent signal, heterozygous genotype on the basis of a VIC/FAM fluorescent signal, and homozygous mutated genotype on the basis of a FAM fluorescent signal.

Quantification of AGE. The levels of AGE were determined, as previously described by Campos et al (29), with some minor modifications. The serum samples were diluted to 1:50 with phosphate buffered saline (PBS; pH 7.4) and pipetted into a black microtiter plate. Subsequently, the fluorescence intensity with $\lambda_{\mathrm{exc}}=350 \mathrm{~nm}$ and $\lambda_{\mathrm{em}}=440 \mathrm{~nm}$ was measured using a Sinergy HT microplate absorbance reader (Biotek Instruments, Inc., Winooski, VT, USA) and expressed as $\mathrm{AU} / \mathrm{ml}$.

Quantification of AOPP. The serum concentrations of AOPP were determined, as previously described by Witko-Sarsat et al (30). Briefly, $200 \mu \mathrm{l}$ of the diluted serum samples (1:5 in PBS) were pipetted into a microtiter plate with $10 \mu 11.16 \mathrm{M} \mathrm{KI}$ and $20 \mu \mathrm{l}$ acetic acid (Sigma-Aldrich, St. Louis, MO, USA). Absorbance was measured at $340 \mathrm{~nm}$ using a Sinergy HT microplate absorbance reader, with a calibration curve of $0-128 \mu \mathrm{M}$ chloramine $\mathrm{T}$, for AOPP quantification.

Statistical analysis. The data were analyzed using two-tailed analysis of variance followed by Tukey's post hoc test using Prism version 5.01 (GraphPad software, La Jolla, CA, USA). $\mathrm{P}<0.05$ was considered to indicate a statistically significant difference.

\section{Results}

Subject characteristics. The data regarding the demographic and lifestyle characteristics of the exposed subjects are presented in Table I. The subjects were exposed to a mixture of pesticides (including imidacloprid, cypermethrin, pirimetanil, dimetomorf and carbendazim), with prevalent use of chlorpyrifos, which is an OP. No cases of exposure to pesticides from non-occupational sources were registered. No infectious or inflammatory diseases and no drug use was reported in the subjects in the three months preceding the survey. The majority of subjects had an adequate intake of food rich in antioxidants, did not smoke and did not abuse alcohol.

Expression levels of $A G E$ and AOPP are significantly decreased in farmers with the 192RR genotype. The levels of AGE and AOPP are presented in Table II. A significant decrease in the levels of AOPP were observed in the subjects with the $192 \mathrm{RR}$ mutated genotype $(0.64 \mathrm{nmol} / \mathrm{ml} ; \mathrm{P}<0.01)$, compared with the subjects with the WT $(1.76 \mathrm{nmol} / \mathrm{ml})$ and heterozygotic $(1.60 \mathrm{nmol} / \mathrm{ml})$ 192QR genotype. A similar trend was observed in the levels of serum AGE, which were significantly lower in the subjects with the 192RR mutated genotype $(14,7221 \mathrm{AU} / \mathrm{ml} ; \mathrm{P}<0.05)$, compared with those with the WT $(16,1400 \mathrm{AU} / \mathrm{ml})$ and heterozygotic 192QR $(15,2312 \mathrm{AU} / \mathrm{ml})$ genotypes.

\section{Discussion}

The present study demonstrated the presence of an association between the PON1 gene polymorphism and serum levels of AGE and AOPP in farmers occupationally exposed to pesticides.

The frequency of the PON1 Q allele at position 192 was higher, compared with that of the $\mathrm{R}$ allele, and homozygotic 192QQ WT genotypes were the most frequent (51\%) within the population examined in the present study, These results are concordant with those of previous studies (22,31-33). The results of the present study regarding the frequency of the $\mathrm{R}$ allele in the exposed population are comparable with those reported for the European population, with an $\mathrm{R}$ allele frequency ranging between 0.313 and 0.248 (26). Furthermore, no association between the PON1 polymorphism and other risk factors, including age, tobacco and alcohol consumption, were observed in the present study.

Due to the role of PON1 in metabolizing OP insecticides, the protective role of PON1 against the toxic effects of different toxic agents has been investigated in previous years. In vivo studies have confirmed that high levels of plasma PON1 lead to an increase in resistance to OP, with the PON1 $192 \mathrm{R}$ isoform providing improved protection, compared with 
the 192Q isoform against certain oxon derivates, including chlorpyrifos oxon $(34,35)$.

The results of several studies support the hypothesis that pesticides induce oxidative stress in populations exposed to pesticides $(36,37)$. Various pesticides, including OPs, are capable of generating free radicals, including hydrogen peroxide, superoxide and hydroxyl; and novel compounds, including AGE and AOPP. These oxidants have been implicated in the toxicity of pesticides due to their harmful effects on human health (38).

In the subjects examined in the present study, a significant decrease in the levels of AGE and AOPP were observed in subjects with the 192RR genotype, compared with those with the WT and 192QR genotypes. In addition, compared with AGE, the levels of AOPP provided a more sensitive biomarker, with improved correlation with the PON1 genotype.

The majority of subjects had an healthy lifestyle and all were in good health, therefore, the predominant confounding factors for oxidative stress generation were excluded.

Due to the high catalytic activity of paraxonase, the 192RR genotype has been identified as an important genetic predictor of susceptibility to the toxic effects of ROS associated with OP pesticide exposure (37). The 192RR genotype determines a minor risk for the development of oxidative damage. The measurement of AOPP levels may provide a biomarker for the effects in subjects exposed to pesticides.

In conclusion, the results of the present study indicated that chronic OP pesticide exposure may result in long-lasting oxidative stress, and polymorphic genes encoding PON1 are genetic determinants of OP pesticide toxicity, which significantly interact with pesticide exposure to modify antioxidant enzyme activities. The interaction between genetic environment and pesticide exposure may be important in the development of numerous chronic and degenerative diseases, including cancer and neurodegeneration (38). The early identification of these chemical biomarkers is useful to promote health protection and prevention programs for populations which are more susceptible to the adverse effects of OP pesticide exposure.

\section{References}

1. Donaldson D, Kiely T and Grube A: Pesticide's industry sales and usage 1998-1999 market estimates. US Environmental Protection Agency, Washington, 2002.

2. Kapka-Skrzypczak L, Cyranka M, Skrzypczak M and Kruszewski M. Biomonitoring and biomarkers of organophosphate pesticides exposure - state of the art. Ann Agric Environ Med 18: 294-303, 2011.

3. Wesseling C, McConnell R, Partanem T and Hogstdt C: Agricultural pesticides in developing countries: Health effects and research needs. Int J Health Serv 27: 273-308, 1997.

4. He F: Biological monitoring of exposure to pesticides: Current issues. Toxicol Lett 108: 277-283, 1999.

5. Hernández AF, Casado I, Pena G, Gil F, Villanueva E and Pla A: Low level of exposure to pesticides leads to lung dysfunction in occupationally exposed subjects. Inhal Toxicol 20: 839-849, 2008

6. Mehrpour O, Karrari P, Zamani N, Tsatsakis AM and Abdollahi M: Occupational exposure to pesticides and consequences on male semen and fertility: A review. Toxicol Lett 230: 146-156, 2014.

7. Fenga C, Gangemi S, Catania S, De Luca A and Costa C: IL-17 and IL-22 serum levels in greenhouse workers exposed to pesticides. Inflamm Res 63: 895-897, 2014.

8. Kisby GE, Muniz JF, Scherer J, Lasarev MR, Koshy M, Kow YW and McCauley L: Oxidative stress and DNA damage in agricultural workers. J Agromedicine 14: 206-214, 2009.
9. Atherton KM, Williams FM, Egea González FJ, Glass R, Rushton S, Blain PG and Mutch E: DNA damage in horticultural farmers: A pilot study showing association with organophosphate pesticide exposure. Biomarkers 14: 443-451, 2009.

10. Bassil KL, Vakil C, Sanborn M, Cole DC, Kaur JS and Kerr KJ: Cancer health effects of pesticides: Systematic review. Can Fam Physician 53: 1704-1711, 2007.

11. Orsi L, Delabre L, Monnereau A, Delval P, Berthou C, Fenaux P Marit G, Soubeyran P, Huguet F, Milpied N, et al: Occupational exposure to pesticides and lymphoid neoplasms among men: Results of a French case-control study. Occup Environ Med 66: 291-298, 2009.

12. Persson EC, Graubard BI, Evans AA, London WT, Weber JP, LeBlanc A, Chen G, Lin W and McGlynn KA: Dichlorodiphenyltrichloroethane and risk of hepatocellular carcinoma. Int J Cancer 131: 2078-2084, 2012.

13. Alavanja MC, Ross MK and Bonner MR: Increased cancer burden among pesticide applicators and others due to pesticide exposure. CA Cancer J Clin 63: 120-142, 2013.

14. Schinasi L and Leon ME: Non-Hodgkin lymphoma and occupational exposure to agricultural pesticide chemical groups and active ingredients: A systematic review and meta-analysis. Int J Environ Res Public Health 11: 4449-4527, 2014.

15. Sanborn M, Kerr KJ, Sanin LH, Cole DC, Bassil KL and Vakil C: Non-cancer health effects of pesticides: Systematic review and implications for family doctors. Can Fam Physician 53: 1712-1720, 2007.

16. Prakasam A, Sethupathy S and Lalitha S: Plasma and RBCs antioxidant status in occupational male pesticide sprayers. Clin Chim Acta 310: 107-112, 2001.

17. Abdollahi M, Ranjbar A, Shadnia S, Nikfar S and Rezaie A: Pesticides and oxidative stress: A review. Med Sci Monit 10: RA141-RA147, 2004.

18. Muniz JF, McCauley L, Scherer J, Lasarev M, Koshy M, Kow YW, Nazar-Stewart V and Kisby GE: Biomarkers of oxidative stress and DNA damage in agricultural workers: A pilot study. Toxicol Appl Pharmacol 227: 97-107, 2008.

19. Lukaszewicz-Hussain A: Role of oxidative stress in organophosphate insecticide toxicity-short review. Pestic Biochem Physiol 98: 145-150, 2010.

20. Kalousová M, Zima T, Tesar V, Dusilová-Sulková S and Skrha J: Advanced glycoxidation end products in chronic diseases-clinical chemistry and genetic background. Mutat Res 579: 37-46, 2005.

21. Dalle-Donne I, Rossi R, Colombo R, Giustarini D and Milzani A: Biomarkers of oxidative damage in human disease. Clin Chem 52: 601-623, 2006.

22. Lee BW, London L, Paulauskis J, Myers J and Christiani DC: Association between human paraoxonase gene polymorphism and chronic symptoms in pesticide-exposed workers. J Occup Environ Med 45: 118-122, 2003.

23. Costa LG, Cole TB, Vitalone A and Furlong CE: Measurement of paraoxonase (PON1) status as a potential biomarker of susceptibility to organophosphate toxicity. Clin Chim Acta 352: 37-47, 2005.

24. Kuang XY, Zhou ZJ, Ma XX, Yao F, Wu QE and Chen B: Activity of esterases and effect of genetic polymorphism in workers exposed to organophosphorus pesticides. Zhonghua Lao Dong Wei Sheng Zhi Ye Bing Za Zhi 24: 333-336, 2006 (In Chinese).

25. Matthews AR, Sutter ME and Rentz DE: Serum paraoxonase-1 (PON-1) genotype and exposure to organophosphorous insectides-is there a high-risk population? J Med Toxicol 7: 243-247, 2011

26. Tsatsakis AM, Zafiropoulos A, Tzatzarakis MN, Tzanakakis GN and Kafatos A: Relation of PON1 and CYP1A1 genetic polymorphisms to clinical findings in a cross-sectional study of a Greek rural population professionally exposed to pesticides. Toxicol Lett 186: 66-72, 2009.

27. Androutsopoulos VP, Kanavouras K and Tsatsakis AM: Role of paraoxonase 1 (PON1) in organophosphate metabolism: Implications in neurodegenerative diseases. Toxicol Appl Pharmacol 256: 418-424, 2011.

28. Zafiropoulos A, Linardakis M, Jansen EH, Tsatsakis AM, Kafatos A and Tzanakakis GN: Paraoxonase 1 R/Q alleles are associated with differential accumulation of saturated versus 20:5n3 fatty acid in human adipose tissue. J Lipid Res 51: 1991-2000, 2010.

29. Campos C, Guzmán R, López-Fernández E and Casado A: Evaluation of urinary biomarkers of oxidative/nitrosative stress in children with Down syndrome. Life Sci 89: 655-661, 2011. 
30. Witko-Sarsat V, Friedlander M, Capeillère-Blandin C, Nguyen-Khoa T, Nguyen AT, Zingraff J, Jungers $P$ and Descamps-Latscha B: Advanced oxidation protein products as a novel marker of oxidative stress in uremia. Kidney Int 49: 1304-1313, 1996.

31. Bernal-Hernández YY, Medina-Díaz IM, Barrón-Vivanco BS Robledo-Marenco Mde L, Girón-Pérez MI, Pérez-Herrera NE, Quintanilla-Vega B, Cerda-Flores R and Rojas-García AE: Paraoxonase 1 and its relationship with pesticide biomarkers in indigenous Mexican farmworkers. J Occup Environ Med 56: 281-290, 2014.

32. Zhang X, Sui H, Li H, Zheng J, Wang F, Li B and Zhang Y: Paraoxonase activity and genetic polymorphisms in northern Han Chinese workers exposed to organophosphate pesticides. Exp Biol Med (Maywood) 239: 232-239, 2014.

33. Costa LG, Vitalone A, Cole TB and Furlong CE: Modulation of paraoxonase (PON1) activity. Biochem Pharmacol 69: 541-550, 2005.

34. Li WF, Costa LG, Richter RJ, Hagen T, Shih DM, Tward A, Lusis AJ and Furlong CE: Catalytic efficiency determines the in-vivo efficacy of PON1 for detoxifying organophosphorus compounds. Pharmacogenetics 10: 767-779, 2000.
35. Hernández AF, López O, Rodrigo L, Gil F, Pena G, Serrano JL, Parrón T, Alvarez JC, Lorente JA and Pla A: Changes in erythrocyte enzymes in humans long-term exposed to pesticides: Influence of several markers of individual susceptibility. Toxicol Lett 159: 13-21, 2005.

36. López O, Hernández AF, Rodrigo L, Gil F, Pena G, Serrano JL, Parrón T, Villanueva E and Pla A: Changes in antioxidant enzymes in humans with long-term exposure to pesticides. Toxicol Lett 171: 146-153, 2007.

37. Singh S, Kumar V, Thakur S, Banerjee BD, Rautela RS, Grover SS, Rawat DS, Pasha ST, Jain SK, Ichhpujani RL and Rai A: Paraoxonase-1 genetic polymorphisms and susceptibility to DNA damage in workers occupationally exposed to organophosphate pesticides. Toxicol Appl Pharmacol 252: 130-137, 2011.

38. Hernández AF, Lacasaña M, Gil F, Rodríguez-Barranco M, Pla A, López-Guarnido O: Evaluation of pesticide-induced oxidative stress from a gene-environment interaction perspective. Toxicology 307: 95-102, 2013. 